\title{
Evidence for Persistent Hepatitis C Virus (HCV) Infection in Hemophiliacs
}

\author{
Jean-Pierre Allain," Stephen H. Dailey," Yves Laurian, ${ }^{\star}$ David S. Vallari, * \\ Anne Rafowicz, ${ }^{*}$ Suresh M. Desai, ${ }^{*}$ and Sushil G. Devare* \\ *Abbott Laboratories, Diagnostics Division, Abbott Park, Illinois 60064; and ${ }^{\ddagger}$ International \\ Hemophilia Training Center, Hôpital de Bicetre, Kremlin-Bicetre 94270, France
}

\begin{abstract}
Hepatitis $\mathrm{C}$ virus (HCV) is the major etiologic agent associated with non-A, non-B hepatitis. This study was designed to assess virologic and serologic markers in hemophiliacs exposed to non-heat-treated and/or virus-inactivated plasma derivatives. Serial bleeds from 48 hemophilic patients were analyzed for the presence of HCV viral RNA sequences as detected by polymerase chain reaction (PCR) and antibodies to structural (core) and nonstructural (C-100 and 33C) proteins by specific dot immunoblot assay. All patients exposed to non-heat-treated products, and four of six patients exposed only to virus inactivated products, had evidence of HCV infection. However, over the 5-yr study period, six exposed patients (13\%) consistently lacked detectable anti-C-100 and seven (15\%) lost this antibody. HCV viremia (PCR positive) was found in $91 \%$ of exposed patients, and was significantly more frequent in HIV seropositive hemophiliacs $(P<0.05)$. Six patients had high antibody level to HCV and elevated ALT, but appeared to clear viremia. Four hemophiliacs were HCV seropositive but lacked detectable viremia. These data indicate that hemophiliacs remain persistently infected by $\mathrm{HCV}$ and that antibody to the core antigen of $\mathrm{HCV}$ is a reliable marker of this transfusion transmissible agent. (J. Clin. Invest. 1991. 88:1672-1679.) Key words: Non-A hepatitis • non-B hepatitis • liver disease • Factor VIII concentrate $\bullet$ Factor IX concentrate $\bullet$ virus inactivation
\end{abstract}

\section{Introduction}

Since the early 1980 s, viral inactivation of plasma derivatives used for the treatment of hemophiliacs has been the object of intensive research. A large number of techniques for inactivation of infectious agents in plasma derivatives ranging from heat treatment at $60-80^{\circ} \mathrm{C}$ in dry, humidified, or liquid state (1-6), to detergents or chemicals (7), have been developed and evaluated in chimpanzees as well as in previously untreated hemophiliacs. Clinical trials showed that most of these methods effectively inactivated HIV but were only partially effective with the agent of non-A, non-B hepatitis. Unequivocal evidence of non-A, non-B hepatitis prevention was obtained only with high temperature $\left(\geq 75^{\circ} \mathrm{C}\right)$, pasteurization in liquid

Address correspondence to Dr. J. P. Allain, Department of Transfusion Medicine, University of Cambridge, Long Road, Cambridge CP2 2PT, England. 1991

Received for publication 1 March 1991 and in revised form 2 July

J. Clin. Invest.

(c) The American Society for Clinical Investigation, Inc $0021-9738 / 91 / 11 / 1672 / 08 \$ 2.00$

Volume 88, November 1991, 1672-1679 phase, or the solvent-detergent (SD) ${ }^{1}$ method (6-8). These clinical results were later confirmed serologically with the discovery of hepatitis $\mathrm{C}$ virus (HCV), the virus implicated in posttransfusion non-A, non-B hepatitis, and the development of screening assays for antibody to HCV. Several studies indicated that the prevalence of antibody to the HCV nonstructural C-100 antigen ranged from 61 to $89 \%$ in patients with hemophilia A receiving non-heat-treated Factor VIII concentrates, and 22 to $56 \%$ in patients receiving exclusively virus-inactivated material (9-13). Investigators raised questions as to why all potentially exposed patients were not seropositive to HCV, and why, over time, between 1985-88, approximately $10 \%$ of seropositive hemophiliacs lost reactivity with the C-100-based screening ELISA $(9,14)$. One hypothesis suggested that some patients may not develop antibody to this HCV nonstructural protein. Alternatively, the use of virus-inactivated products may limit or eliminate HCV antigenic stimulation and patients who no longer produce virus may return to a seronegative state (seroreversion) (14).

In order to test these hypotheses, serial serum samples collected 1985-89 from a group of 48 hemophiliacs were tested to assess the presence of circulating HCV by polymerase chain reaction (PCR) and the immune response to structural and nonstructural antigens of HCV by dot immunoblot. Results indicate that most HCV-infected hemophiliacs remain chronically infected while receiving virus-inactivated plasma derivatives and that antibody to the core antigen of HCV was a very reliable marker of past and present HCV infection.

\section{Methods}

Patients. A group of 48 persons with hemophilia A (40) or $B(8)$ ranging in age from 6 to $63 \mathrm{yr}$ (median 23, mean $24 \mathrm{y}$ ) was clinically monitored one to four times a year between 1985 and 1989 at the International Hemophilia Training Center, Kremlin-Bicetre, France. Standard check-up included clinical examination, measurement of alanine amino transferase (ALT), HIV antibody detection, testing for hepatitis surface antigen (HBsAg), antibody to hepatitis B surface (anti-HBs) and core (anti-HBc) antigens. In addition, residual sera were kept frozen at $-30^{\circ} \mathrm{C}$ in $0.5-\mathrm{ml}$ aliquots. One aliquot of serum for each year was sent frozen in dry ice to the USA, divided into five, 100- $\mu$ l aliquots on arrival, and kept frozen below $-80^{\circ} \mathrm{C}$ until used. Each patient was classified into one of four liver disease evaluation categories on the basis of clinical examination and liver enzyme profile. Category 1 included patients with or without hepatomegaly who had persistently elevated ALT levels ( $\geq 45 \mathrm{IU} /$ liter). Category 2 included patients who developed acute non-A, non-B hepatitis during the course of the study. Category 3 included patients with minor (below twice the upper nor-

1. Abbreviations used in this paper: ALT, alanine amino transferase; anti-HBc, antibody to hepatitis B core; anti-HBs, antibody to hepatitis B surface; Dr, density of reflectance; HBsAg, hepatitis surface antigen; HBV, hepatitis B virus; HCV, hepatitis C virus; PCR, polymerase chain reaction; $\mathrm{SD}$, solvent-detergent. 
mal level), erratic elevation of ALT, and no hepatomegaly. Category 4 included hemophiliacs with no clinical or biological evidence of liver disease. Patients with hemophilia A received a variety of Factor VIIIrich plasma derivatives that were non-heat-treated before October 1985, heat-treated between October 1985 and 1987, and, since 1988, treated by a SD method (7). Before 1985, most patients were treated with freeze-dried cryoprecipitate or intermediate purity Factor VIII concentrate prepared by the Centre National de Transfusion Sanguine (CNTS), Paris, France. However, some patients also received Factor VIII concentrates of American origin. In 1985-87, patients were treated with intermediate purity concentrate heat-treated as humidified powder under high pressure (CNTS) as described (5). Since 1988, all patients were treated exclusively with a high purity SD-treated Factor VIII (Bio-Transfusion, Les Ulis, France). Patients with hemophilia B received Factor IX concentrate (PPSB, CNTS) non-heat-treated, heat-treated, and SD as for patients with hemophilia A. There were six patients (five with severe and one with moderate hemophilia) who received exclusively a combination of heat-treated and SD-treated products. These six patients and nine others were HIV seronegative, whereas 33 patients were HIV seropositive in 1985 and remained positive. 12 patients age 15 or younger had been vaccinated with HEVAC B (Pasteur vaccine) and all had anti-HBs as only marker of hepatitis B. In addition, 2 of the 36 patients who were $\mathrm{HBV}$ infected by transfusion were $\mathrm{HBs} A g$ positive; 34 had anti-HBs, 25 anti-HBc, and one had none of these HBV markers although he had received whole blood and plasma derivatives for more than $30 \mathrm{yr}$.

Detection of HCV genomic sequences by PCR. The genomic RNA isolation, cDNA synthesis, and PCR analysis were performed as described by Weiner et al. (15) with PCR primers described by Kubo et al. (16). Briefly, $50 \mu \mathrm{l}$ of patient serum were incubated in lysis buffer ( 50 $\mathrm{mM}$ Tris pH 8, $1 \mathrm{mM}$ EDTA, $0.1 \mathrm{M} \mathrm{NaCl}, 0.5 \%$ SDS, $100 \mu \mathrm{g} / \mathrm{ml}$ proteinase $\mathrm{K}$ ) for $1 \mathrm{~h}$ at $37^{\circ} \mathrm{C}$. RNA was purified by phenol/chloroform extractions. The cDNA synthesis was performed according to manufacturer's protocols (Bethesda Research Laboratories, Gaithersburg, MD). PCR conditions were: denaturation at $95^{\circ} \mathrm{C}$ for $1 \mathrm{~min}$, annealing at $42^{\circ} \mathrm{C}$ for $2 \mathrm{~min}$, and extension at $72^{\circ} \mathrm{C}$ for $3 \mathrm{~min}$ for 35 cycles. After first round amplification, the PCR-amplified sample was reamplified with a second pair of primers which were internal to the original primer pair. The nested-PCR conditions were the same as the first round except only 30 cycles were performed. The PCR products were analyzed on a $1.2 \%$ agarose gel, blotted to Hybond-N (Amersham Corp., Arlington Heights, IL), and hybridized to a random primed ${ }^{32} \mathrm{P}$-labeled HCV DNA insert. Samples positive by PCR were considered viremic.

Dot blot immunoassay. Antibodies to HCV gene products were assayed with a semiautomated dot blot immunoassay (MATRIX; Abbott Laboratories, North Chicago, IL) which employs an array of purified recombinant antigens spotted on nitrocellulose. This technology has been described in detail $(17,18)$. The test panels consisted of the C-100 antigen, which was purchased from Chiron Corporation (Emeryville, CA), plus polypeptides corresponding to putative $\mathrm{HCV}$ NS-3 (33C), and 5'-structural sequences encoding for the putative core of $\mathrm{HCV}$ (core) which were expressed in Escherichia coli as fusions with cytosine monophosphate keto deoxy octulosonate (CMP-KDO) synthetase (19). Each array also contained procedural controls (anti-human IgG and human IgG) to verify sample and reagent addition, as well as a negative control (casein) to adjust for nonspecific binding to the nitrocellulose surface.

The prepared solid phase was incubated in a reaction cell with the test sample (diluted $1: 100$ ) for $1 \mathrm{~h}$ at $35^{\circ} \mathrm{C}$ followed by sequential 30 min incubations at $35^{\circ} \mathrm{C}$ with biotin-labeled goat anti-human IgG (heavy and light chains), alkaline phosphatase-labeled rabbit antibiotin, and bromochloroindolyl phosphate. Upon completion of the incubation with the chromogen, the nitrocellulose surface was dried and reflectance at defined locations within the array was determined to provide an objective measure of the extent of the individual reactions. Reactivity cutoff values were calculated for each antigen based on a 50-member antibody-negative population; sample to cutoff (S/CO or density of reflectance (Dr) ratio) values $>1$ were considered positive.
For typical HCV-positive donor specimens, antigen reactivities varied linearly with antibody concentration for $\mathrm{S} / \mathrm{CO}$ values $<100$ (data not shown).

Statistical analysis. The two tailed Fischer's exact tests were used to assess statistical differences between comparison groups.

\section{Results}

$H C V$ infection. By serological criteria, 46 out of 48 multitransfused hemophiliacs $(95.8 \%)$ had antibody to HCV. Two patients who had received exclusively heat-treated and SD Factor VIII concentrates had no convincing clinical, serologic, or virologic evidence of HCV infection. All $46 \mathrm{HCV}$ seropositive patients had antibodies to at least two of the tested antigens. However, among these, six were consistently negative for anti-C100 and one was consistently negative for anti-33C, but all were positive for antibody to the core protein. The mean Dr ratio calculated on the highest ratio for each patient was 48.5 \pm 48.2 for anti-C-100, 234.0 \pm 92.1 for anti-33C, and $206.9 \pm 54.1$ for anticore. Immunoreactivity to $C-100$ often appears transient and markedly lower than to the $33 \mathrm{C}$ or core antigens, although the Dr ratios cannot be directly compared due to the presence of an unknown number of available epitopes for each protein on the reactive areas.

$H C V$ viremia. $\mathrm{HCV}$ viremia was assessed by PCR using primer pairs from the nonstructural NS3/NS4 region of the viral genome. Overall, 42 out of 46 patients $(91.3 \%)$ with serological evidence of $\mathrm{HCV}$ infection were found viremic in at least one of the three to five samples collected over a period of 4 to $5 \mathrm{y}$. The data collected were grouped according to four different patterns. Patterns 1, 3, and 4 are presented in detail in Table I and summarized in Table II.

Pattern 1 included 10 patients whose samples all tested positive for HCV genome in serum. In addition to apparent, persistent $\mathrm{HCV}$ viremia based on PCR data, it is significant that all patients were also seropositive for HIV. Nine patients had either clear (seven) or moderate (two) signs of liver disease and only patient 39 had consistently normal ALT level. HCV antibodies to the three antigens tested were present in all patients on entry. Over time, antibody level to C-100 tended to decline in seven patients and became undetectable in four of them: The mean maximum Dr ratio was $77.5 \pm 62.7$ (Table II). Antibody to $33 \mathrm{C}$ was initially at high or moderate level, and decreased significantly during the course of the study in five patients. Except for patient 38, antibody to core was at high level in all patients and remained rather stable during the study period.

Pattern 2 included 26 patients (56.5\%) whose $\mathrm{HCV}$ viremia was intermittently detectable (Table II). Due to the large number of patients in this group and the absence of particular features, serial sample results are not presented in Table I. Acute (two patients) or chronic liver disease (11 patients) was frequent, while four patients showed no sign of liver abnormality. HIV seropositivity was found in 18 patients $(69 \%)$ from this group. Four patients had no detectable antibody response to C-100 (three patients) or 33C (one patient); all responded to the core protein. The mean Dr ratios of antibody to C-100, 33C, and core were similar to group 1 (Table II). During the study period, antibody to $\mathrm{C}-100$ ratio declined in 13 patients, becoming undetectable in three of them. Antibody to $33 \mathrm{C}$ also declined in 13 patients and as did antibody to core in four patients. 
Table I. HCV Viremia, Antibody to HCV, Liver Disease, and HIV Status in Hemophiliacs with Patterns 1, 3, and 4

\begin{tabular}{|c|c|c|c|c|c|c|c|c|}
\hline \multirow[b]{2}{*}{ Patient } & \multirow[b]{2}{*}{ Date } & \multirow{2}{*}{$\begin{array}{l}\text { HCV } \\
\text { RNA }\end{array}$} & \multicolumn{3}{|c|}{ Dot immunoblot (S/CO) } & \multirow{2}{*}{$\begin{array}{l}\text { Alt* }^{*} \\
\text { level }\end{array}$} & \multirow{2}{*}{$\begin{array}{l}\text { HIV antibody } \\
\text { status }\end{array}$} & \multirow{2}{*}{$\begin{array}{l}\text { Liver* } \\
\text { disease }\end{array}$} \\
\hline & & & $\mathrm{C}-100$ & $33-\mathrm{C}$ & Core & & & \\
\hline \multicolumn{9}{|c|}{ a. Pattern 1} \\
\hline \multirow[t]{5}{*}{5} & $11-84$ & + & 46 & 324 & 205 & 46 & Pos & 3 \\
\hline & $06-86$ & + & 30 & 272 & 201 & 51 & & \\
\hline & $08-87$ & + & 10 & 297 & 252 & 33 & & \\
\hline & $08-88$ & + & 4 & 250 & 234 & 20 & & \\
\hline & $10-89$ & + & 1 & 74 & 149 & 21 & & \\
\hline \multirow[t]{5}{*}{13} & $04-85$ & + & 41 & 145 & 182 & 80 & Pos & 1 \\
\hline & $02-86$ & + & 39 & 110 & 222 & 46 & & \\
\hline & $08-87$ & + & 20 & 19 & 238 & 23 & & \\
\hline & $09-88$ & + & & & & 44 & & \\
\hline & $06-89$ & + & 7 & 4 & 193 & 39 & & \\
\hline \multirow[t]{5}{*}{20} & $06-85$ & + & 13 & 72 & 171 & 179 & Pos & 1 \\
\hline & $06-86$ & + & 6 & 42 & 126 & 158 & & \\
\hline & $11-87$ & + & 0 & 1 & 260 & 156 & & \\
\hline & $07-88$ & + & 0 & 1 & 158 & 99 & & \\
\hline & $08-89$ & + & 0 & 0 & 120 & 117 & & \\
\hline \multirow[t]{3}{*}{28} & $01-87$ & + & & & & 32 & Pos & 1 \\
\hline & $04-88$ & + & 145 & 267 & 78 & 121 & & \\
\hline & 09-89 & + & 177 & 298 & 83 & 138 & & \\
\hline \multirow[t]{4}{*}{37} & $06-86$ & + & 60 & 258 & 160 & 34 & Pos & 1 \\
\hline & $04-87$ & + & 89 & 304 & 102 & 45 & & \\
\hline & $10-88$ & + & 83 & 284 & 105 & 17 & & \\
\hline & $09-89$ & + & & & & 60 & & \\
\hline \multirow[t]{5}{*}{38} & $01-85$ & + & 29 & 290 & 3 & 138 & Pos & 1 \\
\hline & $02-86$ & + & 31 & 220 & 9 & 87 & & \\
\hline & $04-87$ & + & ND & & & 85 & & \\
\hline & $04-88$ & + & 25 & 76 & 6 & 95 & & \\
\hline & $10-89$ & + & 14 & 48 & 5 & 120 & & \\
\hline \multirow[t]{5}{*}{39} & $05-85$ & + & 83 & 294 & 193 & & Pos & 4 \\
\hline & $01-86$ & + & 155 & 291 & 147 & 28 & & \\
\hline & $01-87$ & + & 62 & 206 & 177 & 25 & & \\
\hline & $02-88$ & + & 86 & 231 & 98 & 14 & & \\
\hline & $01-89$ & + & $\mathrm{ND}^{8}$ & & & 25 & & \\
\hline \multirow[t]{5}{*}{40} & $03-85$ & + & 22 & 227 & 130 & 40 & Pos & 3 \\
\hline & $04-86$ & + & 5 & 159 & 211 & 42 & & \\
\hline & $10-87$ & + & 3 & 110 & 161 & 23 & & \\
\hline & $10-88$ & + & 2 & 10 & 171 & 79 & & \\
\hline & $09-89$ & + & 0 & 26 & 119 & 43 & & \\
\hline \multirow[t]{5}{*}{45} & $05-85$ & + & 173 & 283 & 126 & 77 & Pos & 1 \\
\hline & $05-86$ & + & 101 & 319 & 230 & 75 & & \\
\hline & $04-87$ & + & 93 & 268 & 138 & 126 & & \\
\hline & $08-88$ & + & 54 & 367 & 217 & 165 & & \\
\hline & $08-89$ & + & 17 & 269 & 178 & 152 & & \\
\hline 48 & $01-85$ & + & 2 & 301 & 129 & & Pos & 1 \\
\hline & $08-86$ & + & 28 & 247 & 222 & 152 & & \\
\hline & 03-87 & + & 19 & 267 & 136 & 148 & & \\
\hline & $05-88$ & + & 11 & 340 & 196 & 110 & & \\
\hline & 06-89 & + & 0 & 303 & 182 & 80 & & \\
\hline b. Patte & & & & & & & & \\
\hline 9 & $02-85$ & + & 1 & 68 & 196 & 60 & Pos & 1 \\
\hline & $10-86$ & + & 1 & 39 & 170 & 61 & & \\
\hline & $09-87$ & + & 0 & 0 & 177 & 57 & & \\
\hline & $12-88$ & - & 0 & 0 & 177 & 57 & & \\
\hline
\end{tabular}


Table I. (Continued)

\begin{tabular}{|c|c|c|c|c|c|c|c|c|}
\hline \multirow[b]{2}{*}{ Patient } & \multirow[b]{2}{*}{ Date } & \multirow{2}{*}{$\begin{array}{l}\text { HCV } \\
\text { RNA }\end{array}$} & \multicolumn{3}{|c|}{ Dot immunoblot (S/CO) } & \multirow{2}{*}{$\begin{array}{l}\text { Alt* } \\
\text { level }\end{array}$} & \multirow{2}{*}{$\begin{array}{l}\text { HIV antibody } \\
\text { status }\end{array}$} & \multirow{2}{*}{$\begin{array}{l}\text { Liver }^{+} \\
\text {disease }\end{array}$} \\
\hline & & & C-100 & $33-\mathrm{C}$ & Core & & & \\
\hline \multirow[t]{5}{*}{11} & $01-85$ & + & 26 & 220 & 183 & 19 & Pos & 3 \\
\hline & $04-86$ & + & 19 & 239 & 206 & 16 & & \\
\hline & $04-87$ & + & 37 & 289 & 204 & 10 & & \\
\hline & $09-88$ & - & 7 & 321 & 292 & 50 & & \\
\hline & $12-89$ & - & 0 & 359 & 306 & 44 & & \\
\hline \multirow[t]{5}{*}{12} & $01-85$ & + & 27 & 202 & 188 & 34 & $\mathrm{Neg}$ & 4 \\
\hline & $04-86$ & + & 14 & 180 & 186 & 33 & & \\
\hline & $04-87$ & - & 27 & 237 & 150 & 23 & & \\
\hline & $03-88$ & - & 14 & 249 & 279 & 19 & & \\
\hline & $03-89$ & - & 9 & 205 & 304 & 43 & & \\
\hline \multirow[t]{4}{*}{15} & $05-85$ & + & 0 & 228 & 180 & 40 & $\mathrm{Neg}$ & 3 \\
\hline & 86 & + & 3 & 283 & 128 & 45 & & \\
\hline & $04-88$ & - & 3 & 299 & 255 & 28 & & \\
\hline & $06-89$ & - & 4 & 301 & 227 & 66 & & \\
\hline \multirow[t]{5}{*}{18} & $02-85$ & + & 0 & 17 & 227 & 30 & Pos & 3 \\
\hline & $01-86$ & + & 0 & 3 & 217 & 28 & & \\
\hline & $07-87$ & - & 0 & 3 & 275 & 16 & & \\
\hline & $07-88$ & - & 0 & 3 & 283 & 40 & & \\
\hline & $02-89$ & - & 0 & 0 & 138 & 47 & & \\
\hline \multirow[t]{5}{*}{32} & $06-85$ & + & 1 & 218 & 82 & 42 & Pos & 1 \\
\hline & $05-86$ & + & 1 & 255 & 79 & 31 & & \\
\hline & $09-87$ & + & 0 & 286 & 149 & 23 & & \\
\hline & $09-88$ & + & 0 & 264 & 164 & 30 & & \\
\hline & $06-89$ & - & 0 & 271 & 84 & 58 & & \\
\hline \multicolumn{9}{|l|}{ Pattern 4} \\
\hline \multirow[t]{5}{*}{19} & $03-85$ & - & 39 & 234 & 67 & 56 & $\mathrm{Neg}$ & 4 \\
\hline & $11-86$ & - & 3 & 54 & 5 & 14 & & \\
\hline & $05-87$ & - & 4 & 46 & 9 & 18 & & \\
\hline & $05-88$ & - & 2 & 31 & 6 & 13 & & \\
\hline & $02-89$ & - & 2 & 31 & 6 & 19 & & \\
\hline \multirow[t]{5}{*}{26} & $09-85$ & - & ND & & & 51 & Pos & 1 \\
\hline & $02-86$ & - & 37 & 134 & 191 & 57 & & \\
\hline & $02-87$ & - & 9 & 79 & 187 & 39 & & \\
\hline & $10-88$ & - & 28 & 256 & 115 & 39 & & \\
\hline & 03-89 & - & 0 & 36 & 151 & 59 & & \\
\hline \multirow[t]{5}{*}{29} & $07-85$ & - & 7 & 257 & 237 & 135 & Neg & 1 \\
\hline & $07-86$ & - & 19 & 247 & 204 & 186 & & \\
\hline & $07-87$ & - & 10 & 204 & 234 & 36 & & \\
\hline & $07-88$ & - & 1 & 121 & 219 & 15 & & \\
\hline & 07-89 & - & 3 & 313 & 132 & 223 & & \\
\hline \multirow[t]{5}{*}{42} & $03-85$ & - & 59 & 210 & 178 & 81 & Pos & 1 \\
\hline & $03-86$ & - & 70 & 321 & 228 & 85 & & \\
\hline & $04-87$ & - & 64 & 292 & 220 & 89 & & \\
\hline & $04-88$ & - & 66 & 299 & 164 & 52 & & \\
\hline & 06-89 & - & 81 & 290 & 163 & 195 & & \\
\hline 27 & $09-85$ & - & 0 & 0 & 0 & 6 & $\mathrm{Neg}$ & 4 \\
\hline & $10-86$ & - & 0 & 0 & 0 & 14 & & \\
\hline & $10-87$ & - & 0 & 0 & 0 & 13 & & \\
\hline & $09-88$ & - & 0 & 0 & 0 & 50 & & \\
\hline & $09-89$ & - & 0 & 0 & 0 & 18 & & \\
\hline 33 & $08-86$ & +11 & 0 & 0 & 0 & 20 & $\mathrm{Neg}$ & 4 \\
\hline & $07-88$ & - & 0 & 0 & 0 & 10 & & \\
\hline & $07-89$ & - & 0 & 0 & 0 & 13 & & \\
\hline
\end{tabular}

* In IU/liters, upper normal level is $46 \mathrm{IU} /$ liters.

$\$ 1$ corresponds to chronic liver disease; 2 corresponds to acute non-A, non-B hepatitis becoming chronic; 3 indicates minor, erratic elevation of ALT level; 4 indicates consistently normal ALT level and normal clinical examination.

${ }^{8} \mathrm{ND}$, Not done.

"This patient came to the Center for check-up once a year from Morocco. No additional sample was available to verify this surprising result obtained in two separate experiments. 


\begin{tabular}{|c|c|c|c|c|c|c|c|c|c|c|c|}
\hline \multirow{2}{*}{$\begin{array}{l}\text { Patient } \\
\text { group }\end{array}$} & \multicolumn{2}{|c|}{ HCV cDNA PCR } & \multicolumn{3}{|c|}{$\begin{array}{l}\text { Mean HCV antibody* } \\
\text { DR ratio }( \pm S D)\end{array}$} & \multicolumn{4}{|c|}{ Liver disease $^{*}$} & \multicolumn{2}{|c|}{ HIV antibody } \\
\hline & Pattern' & Patient No. & $C-100$ & C-33 & Core & 1 & 2 & 3 & 4 & POS & NEG \\
\hline 1 & $+/+$ & 10 & $\begin{array}{c}77.5 \\
(48.5)\end{array}$ & $\begin{array}{l}266.1 \\
(87.6)\end{array}$ & $\begin{array}{l}185.8 \\
(76.8)\end{array}$ & 7 & & 2 & 1 & 10 & \\
\hline 2 & $+1-$ & 26 & $\begin{array}{c}46.6 \\
(42.7)\end{array}$ & $\begin{array}{l}223.2 \\
(87.2)\end{array}$ & $\begin{array}{l}195.5 \\
(55.1)\end{array}$ & 11 & 2 & 9 & 4 & 18 & 8 \\
\hline 3 & $+1--$ & 6 & $\begin{array}{c}11.3 \\
(15.0)\end{array}$ & $\begin{array}{c}213.3 \\
(125.9)\end{array}$ & $\begin{array}{l}251.3 \\
(54.0)\end{array}$ & 2 & & 3 & 1 & 4 & 2 \\
\hline 4 & $-1-$ & 4 & $\begin{array}{c}44.0 \\
(22.7)\end{array}$ & $\begin{array}{l}281.0 \\
(36.9)\end{array}$ & $\begin{array}{l}180.7 \\
(67.9)\end{array}$ & 3 & & & 1 & 2 & 2 \\
\hline
\end{tabular}

* Calculated as mean of maximum reflectance to background ratio observed in each patient.

¿ See Table I.

$+/+$ positive in all tested samples; $+/-$ intermittently positive; $+/--$ initially positive becoming negative; $-/-$ consistently negative.

Pattern 3 included six patients who were initially viremic and subsequently became negative by PCR. As shown in Table $I b$, these patients had chronic (two patients) or minor liver disease (three patients), and one patient had no sign of liver disease. ALT levels were mostly normal or less than twice the upper normal level. Three patients had no detectable antibody to C-100; the other three had either low or declining levels of antibody. In contrast, four had consistently high anti-33C and two had low antibody titers that became undetectable. All patients had consistently high anticore immune response. When compared with patients in pattern 1 , the mean maximum of anti-C-100 was significantly lower in patients with pattern $3(P$ $<0.05)$ and the level of anticore was higher although the difference was not significant.

Pattern 4 included four patients with no evidence of $\mathrm{HCV}$ viremia, although two of them (patients 29 and 42, Table Ic) had severe chronic hepatitis. Patient 19 (Fig. 1) was HIV antibody negative, had no sign of liver disease, and a decreasing level of all three antibodies to HCV. Patient 26 had fluctuating levels of antibody to $33 \mathrm{C}$ and core, and had no detectable antiC-100 in the final sample. He had a slightly elevated ALT level. Patient 29 also had fluctuating antibody levels, whereas patient 42 had persistently high levels of each antibody. Patients 27

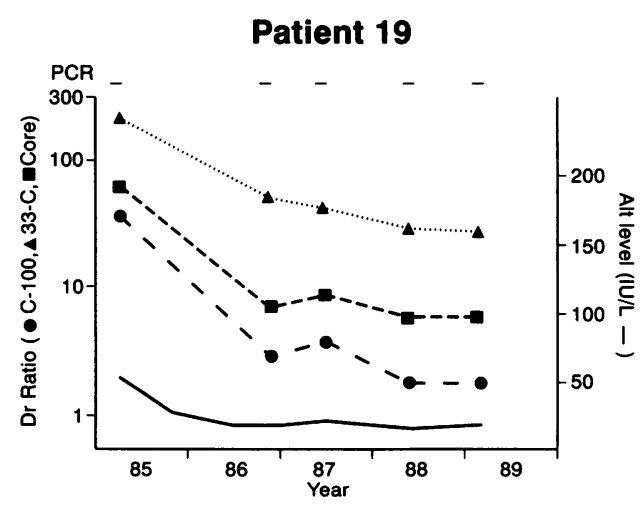

Figure 1. HCV markers in a nonviremic hemophiliac. ALT levels, HCV virologic and serologic markers of patient 19 followed up from 1985 to 1989 . and 33 had no evidence of HCV infection and normal ALT levels, and are presented at the end of Table Ic.

$H C V$ infection in hemophiliacs receiving virus inactivated plasma derivatives. Four out of six patients who received exclusively heat-treated and SD-treated products (Table III) had evidence of HCV infection. Patients 1,25 , and 30 were 6-8 yr old and had severe hemophilia A. In 1985, they already had antibody to the three HCV antigens tested and viremia was found in two to three samples of each patient over the study period. The fourth patient (number 16, Fig. 2), a 22-yr-old with mild hemophilia A, as well as patient 24 (data not shown) who had received both heat-treated and non-heat-treated products, were HCV seronegative in 1985 but seroconverted to HCV. The immune response to $\mathrm{C}-100$ was apparently lower than to $33 \mathrm{C}$ or core. Over time, the antibody level to $\mathrm{C}-100$ declined rapidly but levels of anti-33C and core remained high. HCV viremia was detected one (patient 16) and two years (patient 24) after seroconversion, respectively. Interestingly, patient 24 maintained normal ALT levels during the entire study period.

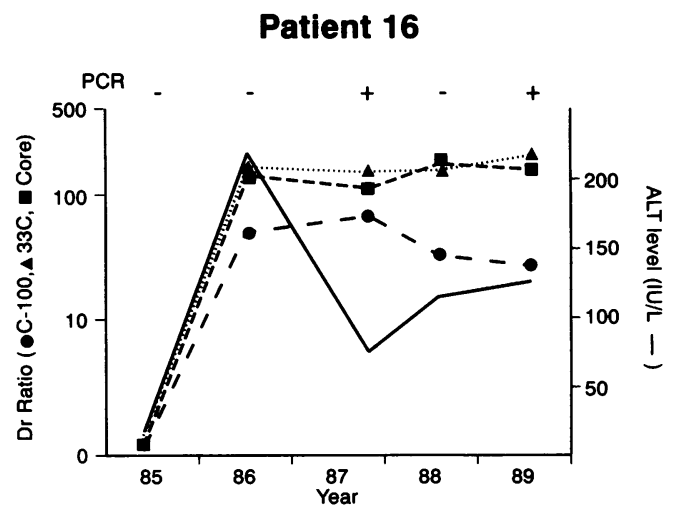

Figure 2. Acute HCV infection in a hemophiliac. ALT levels, HCV virologic and serologic markers of patient 16 , a 22 -yr-old patient with moderate hemophilia A who received exclusively heat or SD-treated Factor VIII concentrate. Acute hepatitis $\mathrm{C}$ is indicated by a peak of ALT, seroconversion to all three markers of $\mathrm{HCV}$ and delayed $\mathrm{HCV}$ viremia. 
Table III. Treatment and Serological Pattern of Six Hemophiliacs Who Received Only Heat-treated Concentrates

\begin{tabular}{|c|c|c|c|c|c|c|c|c|c|}
\hline \multirow{2}{*}{$\begin{array}{l}\text { Patient } \\
\text { No. }\end{array}$} & \multirow{2}{*}{\multicolumn{3}{|c|}{$\begin{array}{l}\text { Type of product used* } \\
\text { (Total number of units) }\end{array}$}} & \multirow{3}{*}{$\begin{array}{c}\begin{array}{c}\text { Maximum } \\
\text { ALT level }\end{array} \\
\text { IU/liter }\end{array}$} & \multicolumn{2}{|c|}{$\mathrm{HBV}^{*}$} & \multicolumn{3}{|c|}{$\mathrm{HCV}^{8}$} \\
\hline & & & & & \multirow{2}{*}{ anti-S } & \multirow[t]{2}{*}{ anti-C } & \multirow{2}{*}{ anti-C-100 } & \multirow[t]{2}{*}{$33-C$} & \multirow[t]{2}{*}{ Core } \\
\hline & & & & & & & & & \\
\hline \multirow[t]{2}{*}{1} & Hemofil T & $(34,450)$ & $1985-87$ & 45 & + & - & + & + & + \\
\hline & CNTS/SD & $(55,000)$ & $1988-89$ & & & & & & \\
\hline 16 & Hemofil T & $(4,000)$ & 1985 & 284 & + & + & + & + & + \\
\hline \multirow[t]{3}{*}{25} & Hemofil T & $(30,560)$ & $1984-85$ & & & & & & \\
\hline & Kryobulin & $(10,000)$ & 1986 & 36 & + & - & + & + & + \\
\hline & CNTS/SD & $(14,000)$ & $1988-89$ & & & & & & \\
\hline \multirow[t]{2}{*}{27} & Kryobulin & $(18,500)$ & $1985-87$ & 50 & + & - & - & - & - \\
\hline & CNTS/SD & $(41,500)$ & $1988-89$ & & & & & & \\
\hline \multirow[t]{2}{*}{30} & CNTS & $(8,000)$ & $1985-87$ & 22 & + & - & - & - & + \\
\hline & CNTS/SD & $(46,000)$ & $1988-89$ & & & & & & \\
\hline 33 & CNTS/PPSB & $(4,000)$ & $1985-89$ & 20 & + & - & - & - & - \\
\hline
\end{tabular}

* Hemofil T was from Hyland, Glendale, CA, USA; CNTS heat-treated, Centre National de Transfusion Sanguine, Les Ulis, France; SD, inactivated with solvent detergent method; Kryobulin (TIM 3) was from Immuno AG, Vienna, Austria.

‡ Only patient 16 was naturally infected with hepatitis B; all others were vaccinated.

Antibody pattern in 1989.

Data compatible with $\mathrm{HCV}$ superinfection during the course of the study were found in three additional cases. Patients 44 (Fig. 3), 41, and 48 (data not shown) had a very low level of antibody to C-100 (range 2-3 Dr ratio) and high levels of antibody to $33 \mathrm{C}$ and core in 1985 . Levels of antibody to C-100 subsequently increased to a mean reflectance ratio of $82.2 \pm 40.1$ (range 28-141) and then decreased over 2-3 yr to a mean level of $36 \pm 29.7$ (range 0-77). In two of the three cases (patients 41 and 44), HCV RNA was not detectable initially but viremia became evident in these patients simultaneously or within $2 \mathrm{yr}$ of the increased C-100 level. All patients had a concomitant elevation of ALT level. Patient 41 was a chronic carrier of hepatitis B surface antigen and had a previously reported delta hepatitis (20). He was receiving French heattreated Factor VIII concentrate approximately three times a month during the period of anti-C-100 response. Patient 44

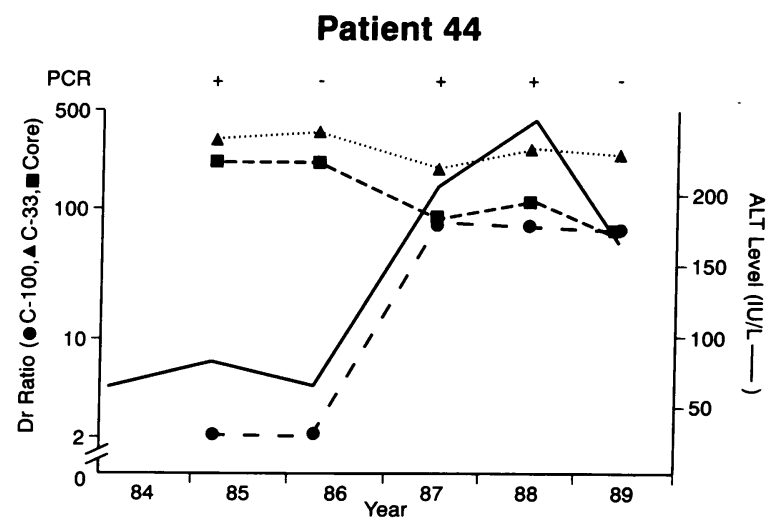

Figure 3. HCV markers suggestive of superinfection in a hemophiliac. ALT levels, HCV virologic and serologic markers of patient 44 who had chronic hepatitis before 1984. While antibody to HCV 33C and core remained at a high level, an immune response to $C-100$ was observed concomitant with a peak of ALT and transitory HCV viremia. was under a prophylactic regimen of $20 \mathrm{U} / \mathrm{kg}$ of heat-treated intermediate purity Factor VIII every other day in 1986-87 (Fig. 3). He had developed immunity against HBV. Patient 48 had hemophilia $B$, received non-heat-treated and subsequently heat-treated PPSB during the period of his response to C-100 (30 U/kg per mo). He had serologic evidence of immunity to HBV.

Role of HIV in HCV infection. The various results collected in this study were analyzed according to the HIV immune status of patients. Among $46 \mathrm{HCV}$ infected hemophiliacs, 33 (72\%) were HIV seropositive and 13 seronegative. The mean levels of antibody to $\mathrm{C}-100,33 \mathrm{C}$ or core, and the variations in levels of antibody to C-100 (undetectable, declining, or consistently high over time), were similar between the two groups. In contrast, the percentage of viremic samples in HIV seropositive patients $(105 / 161$ or $65.2 \%)$ was significantly higher than in seronegative patients $(21 / 60$ or $35 \%, P<0.01)$. A majority of HIV seropositive patients had chronic liver disease. 20 of the 33 seropositive patients $(67 \%)$ were classified as code 1 (See Table I), compared to 5 of the 13 patients $(38 \%)$ in the HIV seronegative group. However, the mean levels of ALT were similar between the two groups (63.6 \pm 51.0 in HIV seropositive vs. $49.0 \pm 60.6$ in HIV seronegative patients).

\section{Discussion}

The data collected in this study differ from previously reported results on HCV in hemophilia. All exposed patients had serological evidence of $\mathrm{HCV}$ infection with the presence of antibody to the core protein of $\mathrm{HCV}$ and, in most cases, to the nonstructural 33C antigen. These two proteins were apparently more immunogenic than $\mathrm{C}-100$ since antibody levels were higher and persisted longer. Thus, our data demonstrate that current seronegativity in $20 \%$ of the patients was related to a decline of antibody to C-100. However, this apparent seroreversion took place despite continued infection as shown in some patients with patterns 1 or 3 (Table I). In other anti-C- 
100 negative patients (15\%), the lack of detection by current screening assays (C-100 based) may be attributed in part to the absence of a significant immune response to $C-100$. These results are consistent with previous observations in similar populations $(10,14,21)$. In contrast, seroreversion for antibody to $33 \mathrm{C}$ was infrequent $(6.5 \%)$ and not observed with anticore. There was no evidence that HIV infection played a significant role in this mechanism since it was observed with similar frequency irrespective of HIV status.

One of the features of this study was the frequency of viremia found in over $90 \%$ of patients over a 5 -yr period during which they received successively heat-treated and SD-treated products. In a limited number of cases, the viremia patterns we described had been identified previously by Garson et al. (21). However, contrary to what was proposed by these investigators, several lines of evidence suggest that most HCV-infected hemophiliacs in this study have a persistent hepatitis $C$ virus infection. First, HCV viremia was found in 42/46 (91.3\%) exposed patients and, during the study period, there was no evidence for a decline in viremia. 29 hemophiliacs were viremic in the 1985 sample and 27 in the 1989 sample. The fact that viremia was detected intermittently in more than $50 \%$ of exposed patients is not surprising since the PCR method is known to have limitations $(15,22,23)$. It has been reported that in persistent viral diseases like HIV or herpes, viral production may fluctuate over time $(24,25)$. Second, although we, like others, have found a clear influence of HIV infection in HCV viral production (Table I $a$ ), apparently persistent $\mathrm{HCV}$ infection indicated by viremia was found in 11 out of 13 HIV seronegative hemophiliacs (85\%). This frequency of HCV infection was not different from the HIV antibody positive group. Third, the cause of viral production does not appear related to superinfection to any large extent. The heat-treated concentrates used from 1985 to 1987 had a lower level of HCV infectivity than non-heat-treated concentrate, and there is no evidence that the SD-treated products might transmit hepatitis $C$ (7). However, as exemplified in Fig. 3, we have found three cases whose antibody profile and viremia pattern suggested superinfection.

Some evidence of virus clearance and disease recovery was found only in a few patients with viremia pattern 3 or 4 (Table I $b$ and $c$ ). Patient 19 (Fig. 1) associated a consistent absence of detectable viremia, a progressive decline of antibody level to all three HCV antigens and a prolonged normalization of ALT level. Patients with pattern 3 may correspond to a stage preceding the features of patient 19 . In four out of six patients, PCR was repeatedly negative and antibody level to $C-100$ was undetectable, low, or declining. However, antibody to core and, in most cases, to $33 \mathrm{C}$ remained elevated, and, except in patient 12 , ALT levels were still moderately or occasionally elevated. In view of the limitations of the PCR method (14) and the potential fluctuations of viremia, one cannot exclude that some, if not all, of these patients might in fact belong to pattern 2. The use of more efficient cDNA synthesis and primer pairs for detection of viral RNA (26), availability of liver biopsies as a source of viral RNA, and testing of prospective samples from these patients may allow us to better categorize them. Unfortunately, liver biopsies are not easily obtained in hemophiliacs.

Patients 26, 29, and 42 appear immune to $\mathrm{HBV}$, are clearly HCV seropositive, and have clinical and biological evidence of chronic liver disease, yet no detectable HCV RNA (Table Ic).
The liver condition is probably not related to $\mathrm{HBV}$ since HBsAg is not detected and antibodies to surface and core antigens are present. In addition, patients 26 and 42 are HIV infected. Four main hypotheses can be proposed to explain these findings. One is a false negativity of the HCV PCR due to inadequate precautions during sample handling or storage, or, alternatively, significant sequence heterogeneity at the primer or probe levels. Such hypothesis could be confirmed by using a primer pair from a more conserved region of the HCV genome such as the $5^{\prime}$ noncoding region (26). A recent report has emphasized the relative diversity of nucleotide sequences in the NS3/NS4 regions that we used in our detection system (14). The second hypothesis is a variant of $\mathrm{HBV}$ or, as previously described, a level of HBV production below the HBsAg detection level (27). However, the presence of both anticore and antisurface antibody to HBV does not support this explanation. The third hypothesis is that the virus may be replicating in the liver but not released in the blood stream. Finally, a still unidentified hepatotropic virus may be involved. This hypothesis is unlikely since similar concentrates have been used for this and other groups of patients.

This study indicates that in hemophilia all exposed subjects have serological markers of $\mathrm{HCV}$ and suggest that $\mathrm{HCV}$ is a persistent infection. This feature may not be the rule in other groups of HCV infected patients since the interaction of HIV, $\mathrm{HCV}$ superinfection and potentially $\mathrm{HBV}$ might interfere with the natural history of $\mathrm{HCV}$ infection. The role of $\mathrm{HBV}$, however, is likely to be minimal since eight of nine HBV vaccinated hemophiliacs had persistent HCV viremia. Prospective studies of patients receiving noninfectious blood products and examination of liver biopsies for the presence of viral RNA in hepatocytes should provide a final answer. The fact that, irrespective of HIV, hemophiliacs can be persistently infected and possibly superinfected with HCV suggest a limited efficacy of their immune system against $\mathrm{HCV}$.

\section{Acknowledgments}

We wish to thank Dr. Stephen Delaney, Serena Alleman, Louise Ducharme, Joseph Stojak, Colleen Downey, Lauren Carney, and James Casey for their invaluable technical help, and Ann Greenlee, who typed the manuscript.

\section{References}

1. Mosseler, J., R. Schmipf, G. Auerswald, H. Bayer, J. Schneider, and G. Hunsmann. 1985. Inability of pasteurized Factor VIII preparations to induce antibodies to HTLV-III after long-term treatment. Lancet. i:1111.

2. Colombo, M., P. M. Mannucci, V. Carnelli, C. Gazengel, G. H. Savidge, and K. Schimpf. 1985. Transmission of non-A, non-B hepatitis by heat-treated Factor VIII concentrate. Lancet. ii:1-4.

3. Preston, F. E., C. R. M. Hay, M. S. Dewar, M. Greaves, and D. R. Triger. 1985. Non-A, non-B hepatitis and heat-treated Factor VIII concentrates. Lancet. ii:213.

4. Mannucci, P. M., M. Colombo, and F. Rodeghiero. 1985. Non-A, non-B hepatitis after Factor VIII concentrates treated by heating and chloroform. Lancet. ii:1013.

5. Morfini, M., V. Carnelli, and G. Mariani. 1986. A prospective multi-center safety study of a steam heated Factor VIII concentrate. Ric. Clin. Lab. 16:244. (Abstr.)

6. Schimpf, K., P. M. Mannucci, W. Kreutz, H. H. Brackmann, G. Auerswald, N. Ciavarella, J. Mosseler, V. DeRosa, B. Kraus, C. Bruckmann, G. Mancuso, U. Mittler, F. Haschke, and M. Morfini. 1987. Absence of hepatitis after treatment with a pasteurized Factor VIII concentrate in patients with hemophilia and no previous transfusions. N. Engl. J. Med. 316:912-922. 
7. Horowitz, M. S., C. Rooks, B. Horowitz, and M. W. Hilgartner. 1988. Virus safety of solvent/detergent-treated anti-haemophilic factor concentrate. Lancet. ii:186-189.

8. Preston, F. E., M. Makris, D. R. Triger, and J. C. E. Underwood. 1990. Prevention of hepatitis C virus infection in haemophiliacs. Lancet. 336:63.

9. Esteban, J. I., R. Esteban, L. Viladomiu, J. C. Lopez-Talavera, J. M. Gonzalez, M. Roget, V. Vargas, J. Genesca, M. Buti, and J. Guardia. 1989. Hepatitis $\mathrm{C}$ virus antibodies among risk groups in Spain. Lancet. 2:294-297.

10. Noel, L., C. Guerois, P. Maisonneuve, F. Verroust, and Y. Laurian. 1989 Antibodies to hepatitis $C$ virus in haemophilia. Lancet. 2:560.

11. Makris, M., F. E. Preston, D. R. Triger, J. C. E. Underwood, Q. L. Choo, G. Kuo, and M. Houghton. 1990. Hepatitis C antibody and chronic liver disease in haemophilia. Lancet. 335:1117-1119.

12. Rumi, M. G., M. Colombo, A. Gringeri, and P. M. Mannucci. 1990. High prevalence of antibody to hepatitis $C$ virus in multi-transfused hemophiliacs with normal transaminase levels. Ann. Intern. Med. 112:379-380.

13. Brettler, D. B., H. J. Alter, J. L. Dienstag, A. D. Forsberg, and P. H. Levine. 1990. Prevalence of hepatitis $C$ virus antibody in a cohort of hemophilia patients. Blood. 76:254-256

14. Simmonds, P., L. Q. Zhang, H. G. Watson, S. Rebus, E. D. Ferguson, P Balfe, G. H. Leadbetter, P. L. Yap, J. F. Peutherer, and C. A. Ludlam. 1990 Hepatitis $\mathrm{C}$ quantification and sequencing in blood products, haemophiliacs and drug users. Lancet. 336:1469-1472.

15. Weiner, A. J., G. Kuo, D. W. Bradley, F. Bonino, G. Saracco, C. Lee, J. Rosenblatt, Q. L. Choo, and M. Houghton. 1990. Detection of hepatitis C viral sequences in non-A, non-B hepatitis. Lancet. 335:1-3.

16. Kubo, Y., K. Takeuchi, S. Boonmar, T. Katayama, Q. L. Choo, G. Kuo, A. J. Weiner, D. W. Bradley, M. Houghton, I. Saito, and T. Miyamura. 1989. A cDNA fragment of hepatitis $\mathrm{c}$ virus isolated from an implicated donor of posttransfusion non-A, non-B hepatitis in Japan. Nucleic Acids Res. 17:1036710372.

17. Donohoe, J., M. Bailey, R. Gray, J. Holen, T. M. Huang, J. Keevan, C.
Mattimiro, C. Putterman, A. Stalder, and J. Defreese. 1989. Enzyme immunoassay for panel testing. Clin. Chem. 35:1874-1877.

18. Mimms, L. D. Vallari, L. Ducharme, P. Holland, I. K. Kuramoto, and J. Zeldis. 1990. Specificity of anti-HCV ELISA assessed by reactivity of three immunodominant HCV regions. Lancet. 336:1591.

19. Bolling, T. J., and W. Mandecki. 1990. An Escherichia coli expression system for high level production of heterologous proteins in fusion with CMPKDO synthetase. Biotechniques. 8:488-490.

20. Fine, J. M., J. P. Allain, D. Rochu, and M. Marneux. 1986. Occurrence of normal circulating proalbumin in a hemophilic A patient after acute hepatitis related to the delta virus. Clin. Chem. 32:1991-1993.

21. Garson, J. A., P. W. Tuke, M. Makris, M. Briggs, S. J. Machin, F. E. Preston, and R. S. Tedder. 1990. Demonstration of viraemia patterns in hemophiliacs treated with hepatitis-C-virus contaminated Factor VIII concentrates. Lancet. 336:1022-1025.

22. Weiner, A. J., M. A. Truett, J. Rosenblatt, J. Han, S. Quan, A. J. Polito, G. Kuo, Q. L. Choo, M. Houghton, C. Agius, E. Page, and M. J. Nelles. 1990. HCV testing in low-risk population. Lancet. 336:695.

23. Garson, J. A., F. E. Preston, M. Makris, M. Briggs, S. J. Machin, F. E Preston, and R. S. Tedder. 1990. Detection by PCR of hepatitis C virus in Factor VIII concentrates. Lancet. 355:1473.

24. Coombs, R. W., A. C. Collier, J. P. Allain, B. Nikora, M. Leuther, G. F Gjerset, and L. Corey. 1989. Plasma viremia in human immunodeficiency virus infection. N. Engl. J. Med. 321:1626-1631.

25. Laurence, J. 1990. Molecular interactions among herpes viruses and human immunodeficiency viruses. $J$. Infect. Dis. 162:338-346.

26. Wang, J. T., T. H. Wang, J. T. Lin, J. C. Sheu, S. M. Lin, and D. S. Chen. 1991. Hepatitis C virus RNA in saliva of patients with post-transfusion hepatitis $\mathrm{C}$ infection. Lancet. 337:48.

27. Lai, M. E., P. Farci, A. Figus, A. Balestrieri, M. Arnone, and G. M. Vyas. 1989. Hepatitis B virus DNA in the serum of Sardinian blood donors negative for the hepatitis B surface antigen. Blood. 73:17-19. 